Original research article

\title{
Barriers to care and missing services from the point of view of informal caregivers in the South Bohemian Region
}

\author{
Hana Hajduchová ${ }^{1}$, Lenka Motlová ${ }^{2}$, Marie Trešlová ${ }^{1}$, Ingrid Baloun ${ }^{2}$, Iva Brabcová ${ }^{1}$, \\ Jana Horová ${ }^{1}$, Sylva Bártlová ${ }^{1}$, Helena Záškodná ${ }^{3}$ \\ ${ }^{1}$ University of South Bohemia in České Budějovice, Faculty of Health and Social Sciences, Institute of Nursing, Midwifery and Emergency Care, \\ České Budějovice, Czech Republic \\ ${ }^{2}$ University of South Bohemia in České Budějovice, Faculty of Health and Social Sciences, Institute of Social and Special-paedagogical Sciences, \\ České Budějovice, Czech Republic \\ ${ }^{3}$ University of South Bohemia in České Budějovice, Faculty of Health and Social Sciences, Institute of Humanities in Helping Professions, \\ České Budějovice, Czech Republic
}

\begin{abstract}
Introduction: Due to the need and current relevance, informal care as a part of the long-term care system as well as the issue of caregivers are included in the Czech National Strategy for the Development of Social Services between 2016 and 2025.

Goal: The goal of this qualitative research was to identify selected areas that informal caregivers encounter in connection with the care of a loved one in the home environment in the South Bohemian Region. The partial goal was to find out what problems informal caregivers face in connection with the use of social or health services.

Methods: We analysed 44 in-depth interviews with 45 informal caregivers. Participants were selected using the "snowball sampling" technique and selection through institutions. The interviews were processed in the ATLAS.ti programme, version 9.

Results: Barriers to informal care include lack of time, the insufficient possibility of physiotherapy at home, lack of information about the possibilities of use and type of services, and entitlement to benefits. Informal caregivers lack relief services, personal assistance, activation services, leisure activities, and transport services.

Conclusions: Due to the complexity of the issue, informal care must be part of a comprehensive approach to caring. We recommend strengthening the competencies of informal caregivers through comprehensive counselling and other services. Individual needs of informal caregivers in the South Bohemian Region must be considered.
\end{abstract}

Keywords: Barriers to care; Care of a loved one; Informal care; Missing services; Needs of caregivers; South Bohemian Region

\section{Introduction}

Informal care as an integral part of the long-term care system is a current topic in both the Czech Republic and abroad (Akgun-Citak et al., 2020; Barbabella et al. 2018; Dixe et al., 2019; Lindeza et al., 2020; Schön and Heap, 2018; Verbakel et al., 2017). Informal and long-term care has also been discussed within the European Committee and the European Social Policy Network. In 2019, the report 'Mapping long-term care quality assurance practices in the EU' was prepared, which focused on an overview of long-term care quality assurance systems and procedures in 28 EU states (Cès and Coster, 2019).

Informal care is the cornerstone of all long-term care systems in Europe and represents a significant share of the overall provision of long-term care in European countries (Zigante, 2018). It should be noted that, in most EU countries, there is no quality framework specific to long-term care (Cès and
Coster, 2019). Individual European countries, such as Germany, Greece, Spain, France, Italy, or Sweden, deal with informal care and its implementation in terms of demographic, legislative, and socio-political aspects. They also address issues related to the quality of care, funding, the changing perception of informal care, and the perception of the role of caregivers in the context of responsibility at European and national level (Gerbery and Bednárik, 2018; Triantafillou et al., 2010).

Informal care as a part of the long-term care system, as well as the issue of caregivers, are included in the Czech National Strategy for the Development of Social Services between 2016 and 2025 due to the current need and relevance. This strategy aims to improve the position of caregivers and family members who provide care. It is not only about increasing the social and financial security of caregivers or increasing the support of caregivers through health and social services, but also about improving the information and education of informal caregivers, the people who are being cared for, and the public. Last

\footnotetext{
* Corresponding author: Hana Hajduchová, University of South Bohemia in České Budějovice, Faculty of Health and Social Sciences, Institute of Nursing, Midwifery and Emergency Care, J. Boreckého 1167/27, 37011 České Budějovice, Czech Republic; e-mail: hajducho@zsf.jcu.cz; http://doi.org/10.32725/kont.2021.031
} 
but not least, it is about increasing the support of caregivers from social workers in their municipalities and labour offices (MoLSA CR, 2015).

The goal of this qualitative research was to identify selected areas that informal caregivers encounter in connection with the care of a loved one in the home environment in the South Bohemian Region. The partial goal was to find out what problems informal caregivers face in connection with the use of social or health services.

\section{Materials and methods}

\section{Participants}

Participants in the qualitative study were informal caregivers with permanent residence in the South Bohemian Region. A total of 45 caregivers took part in the qualitative research (39 women, six men, including one married couple who took care of their son and father). We chose the "snowball sampling" technique for the deliberate selection of participants. We also used the selection through institutions, i.e., the participants were addressed through non-governmental, non-profit organisations, which are the application guarantors of the project "Support for informal caregivers in the South Bohemian Region through audio-visual means, including virtual reality". These were application guarantors based in the South Bohemian Region (ARPIDA, LEDAX, Autis Centrum in České Budějovice, and Domácí hospic sv. Markéty in Strakonice).

We met the condition of maintaining the anonymity of individual participants. The participants were registered under numbers, not names. Their consent was recorded on a dictaphone before the start of the interview. The criterion for inclusion in the research group was the care of a person at home for at least 8 hours a week. The duration of care could not be less than three months. In our research group, the period of care for a loved one in the home environment ranged from 4 months to 20 years.

\section{Collection of data}

The data collection technique was a controlled in-depth interviewing. The interviewers were also involved in the project. Before the start of data collection, a pre-selected group of caregivers was piloted, based on which, the wording of some issues was modified. The interview scenario arose from research questions in line with the project objectives. The interview covered several thematic areas (demographic data of the informal caregiver, care for a close/dependent person, psychosocial needs of the caregiver, use of social benefits, allowances, and social services). The interviewers recorded the interviews on a dictaphone or mobile phone, and the responses were then transcribed. Participants were asked to record the interview and explained the purposes for which the recording would be used. All personal data of the research participants is kept confidential. The interviews were conducted from June to October 2020 and took place by prior arrangement between the interviewer and the informal caregiver. Due to the need to provide care for a family member, most interviews took place at the permanent residence (in the home environment) of the caregiver. The participants were acquainted with the study's focus and goal and offered the opportunity to participate in other phases of the project. Specifically, this was an offer to participate in a self-help group and the chance to use comprehensive counselling services that will be prepared for informal caregivers based on their individual needs and requirements. The length of the interviews ranged from 40 to 90 minutes.

\section{Data analysis}

The ATLAS.ti software, version 9, was used for data analysis as professional software designed to analyse and process qualitative data. Data coding was the focal point of the entire analytical process. Several research team members repeatedly read the individual interviews, and the particular text segments were subsequently coded using open coding. A total of 86 codes emerged from the coding. These codes were then categorised and subcategorised. The data analysis identified six main categories (key themes): (1) areas of care for a loved one, (2) competencies for care, (3) barriers to care, (4) needs of caregivers, (5) psychological support and assistance, and (6) lack of health and social services.

\section{Results}

\section{Basic characteristics of informal caregivers}

The age of the informal caregivers varied. The age of the youngest caregiver was 23 , and the oldest one was 78 years old ( $\mathrm{Ta}$ ble 1). The majority of caregivers lived with the person they cared for in the same household. Informal caregivers from towns, cities and villages within all districts of the South Bohemian Region were selected for the research group. The time required for the provided care depended on the age and relationship between the informal caregiver and the loved one. In the case of informal care for minors, it was 24-hour care seven days a week, excluding children being at school.

\section{Areas of care of a loved one}

Based on the responses of informal caregivers who care for children, adults, and the elderly at home (from the age of 65), a total of eleven areas of care of a loved one were identified, which are shown in Fig. 1.

\section{Competencies of care}

To provide informal care in the home environment, it is undoubtedly necessary to have the prerequisites and abilities to manage specific activities and situations in relation to informal caregivers (competencies). Thus, caregivers need to have competencies for managing care and must also master specific skills, which according to the research, they sometimes lack. Our study showed that these skills are mainly those required for performing hygienic care in the case of a stationary or non-cooperating person, mainly in relation to their weight and positioning on a bed or moving from a bed to a chair or armchair. "No one taught us" (P6). Sometimes practice is needed so it is "not just a theory, but a specific help to the individual" (P21). Among the missing skills, caregivers included communication skills, especially when caring for people who do not speak, suffer from dementia, or have a behavioural disorder and are aggressive. As a specific problem in communication, the participants also mentioned talking about death. "I would certainly welcome something like that" (P38). It is clear from the results that caregivers also need information, advice, and counselling, which they often lack in their care and perceive as psychological help.

Informal caregivers need to have several competencies to provide care for a loved one in the home environment, as shown in Fig. 2. These are areas of competencies regarding personal care (performing personal hygiene, dressing and managing other everyday tasks, etc.), competencies in the area of saturation of physiological needs (individual and life needs of the client), competencies in the area of saturation of psychosocial needs (need for security, safety, acceptance, social 
Table 1. Sociodemographic data of participants

\begin{tabular}{|c|c|c|c|c|}
\hline Participant & Gender & Age & Care of & Length of care \\
\hline P1 & Female & 67 & spouse & more than one year \\
\hline P2 & Male & 51 & daughter & 10 years \\
\hline P3 & Female & 78 & spouse & 9 months \\
\hline P4 & Female & 52 & mother-in-law & 12 months \\
\hline P5 & Female & 68 & mother & 4 months, but have lived together for 5 years \\
\hline P6 & Female & 74 & brother & 4 months \\
\hline P7 & Female & 67 & mother & 7 months \\
\hline P8 & Female & 60 & son, father & 28 years of her son, 3 months of her father* \\
\hline P9 & Male & 61 & son, father & 28 years of her son, 3 months of his father* \\
\hline P10 & Female & 76 & spouse & 4 years \\
\hline P11 & Female & 47 & daughter & 14 years \\
\hline P12 & Female & 63 & spouse & 2.5 years \\
\hline P13 & Male & 55 & son & 20 years \\
\hline P14 & Female & 48 & daughter & 15 years \\
\hline P15 & Female & 44 & daughter & 12 years \\
\hline P16 & Female & 43 & daughter & 7 years \\
\hline P17 & Female & 41 & daughter & 6 years \\
\hline P18 & Female & 46 & son & 14 years \\
\hline P19 & Female & 43 & grandmother & 4 months \\
\hline P20 & Female & 58 & son & 30 years \\
\hline P21 & Female & 62 & daughter & 17 years \\
\hline P22 & Female & 47 & daughter & 14 years \\
\hline P23 & Male & 71 & spouse & 1.5 years \\
\hline P24 & Male & 59 & mother & 2.5 years \\
\hline P25 & Female & 55 & mother-in-law & 2.5 years \\
\hline P26 & Female & 72 & partner & 12 months \\
\hline P27 & Female & 53 & son & 35 years \\
\hline P28 & Female & 44 & daughter & 14 years \\
\hline P29 & Female & 72 & son & 29 years \\
\hline P30 & Female & 52 & daughter & 16 years \\
\hline P31 & Female & 45 & son & 16 years \\
\hline P32 & Female & 45 & son & 14 years \\
\hline P33 & Female & 45 & son & 21 years \\
\hline P34 & Female & 44 & son & 3 years \\
\hline P35 & Female & 78 & spouse & 5 years \\
\hline P36 & Female & 40 & son & 10 years \\
\hline P37 & Female & 40 & father & 3 years \\
\hline P38 & Female & 71 & father & 21 years \\
\hline P39 & Female & 23 & great-aunt & 8 months \\
\hline P40 & Female & 50 & daughter & 13 years \\
\hline P41 & Female & 54 & daughter & 20 years \\
\hline P42 & Male & 42 & daughter & 14 years \\
\hline P43 & Female & 42 & daughter & 14 years \\
\hline P44 & Female & 67 & mother & 14 months \\
\hline P45 & Female & 67 & mother & 2 years \\
\hline
\end{tabular}

${ }^{*}$ An in-depth interview was conducted with a married couple who care for loved ones together.

Source: Project No. TL03000518 "Support for informal caregivers in the South Bohemian Region through audio-visual means, including virtual reality", which is supported by the Technology Agency of the Czech Republic within the ÉTA programme. 


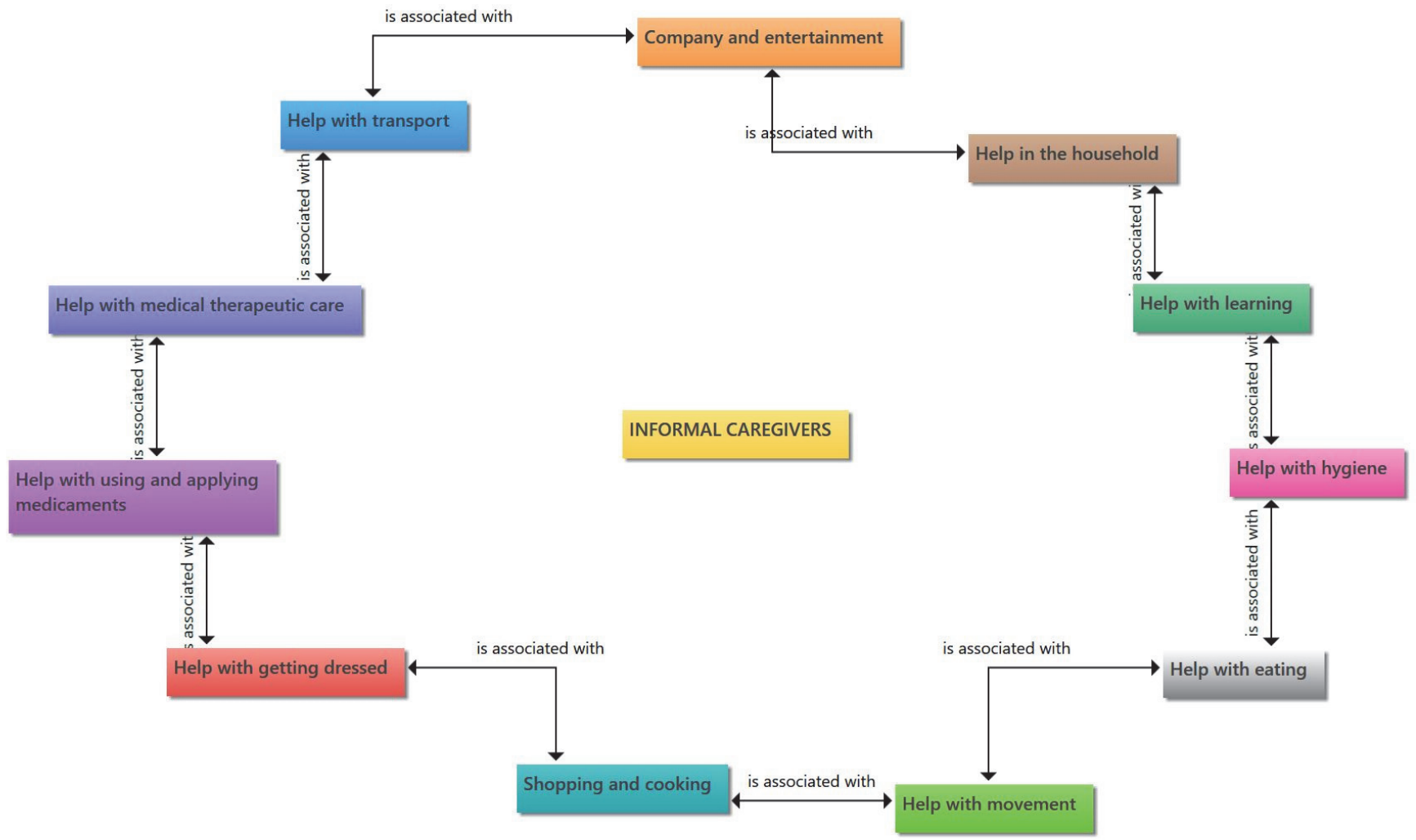

Source: Project No. TL03000518 "Support for informal caregivers in the South Bohemian Region through audio-visual means, including virtual reality", which is supported by the Technology Agency of the Czech Republic within the ÉTA programme.

Fig. 1. Areas of care of a loved one

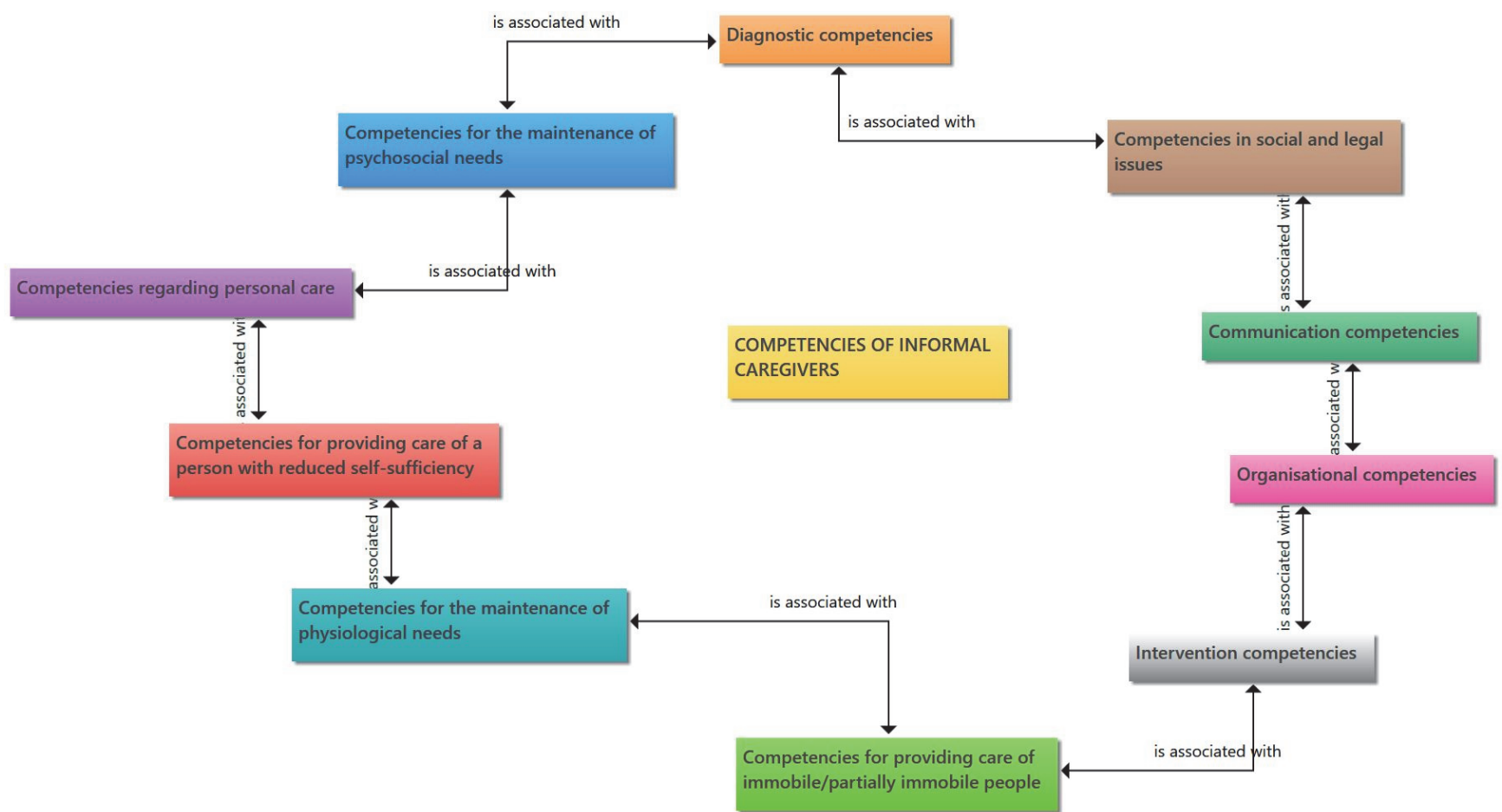

Source: Project No. TL03000518 "Support for informal caregivers in the South Bohemian Region through audio-visual means, including virtual reality", which is supported by the Technology Agency of the Czech Republic within the ÉTA programme.

Fig. 2. Competencies of informal caregivers 
contact, need for one's own identity), communicative competences (mastering the principle of verbal and nonverbal communication, active listening, communication with social and health workers, with officials). Furthermore, these are competencies for providing care for immobile/partially immobile people (positioning on a bed or moving from a bed to a chair or armchair), and competencies for providing care of a person with reduced self-sufficiency. Other necessary skills of caregivers include intervention competencies (problem solving, how to help a loved one, reflection on one's activities, observance of mental hygiene), diagnostic competencies (how close a person thinks, how he or she feels, how he or she behaves, what are the causes of his or her difficulties), organisational competencies (planning care, evaluating the current situation, being flexible and available to a loved one), and competencies in social and legal issues (entitlement to benefits and care, the possibility of using services).

\section{Obstacles in care}

As part of the qualitative research, we focused on identifying the obstacles that informal caregivers encounter when caring for a loved one at home in the South Bohemian Region (Fig. 3).

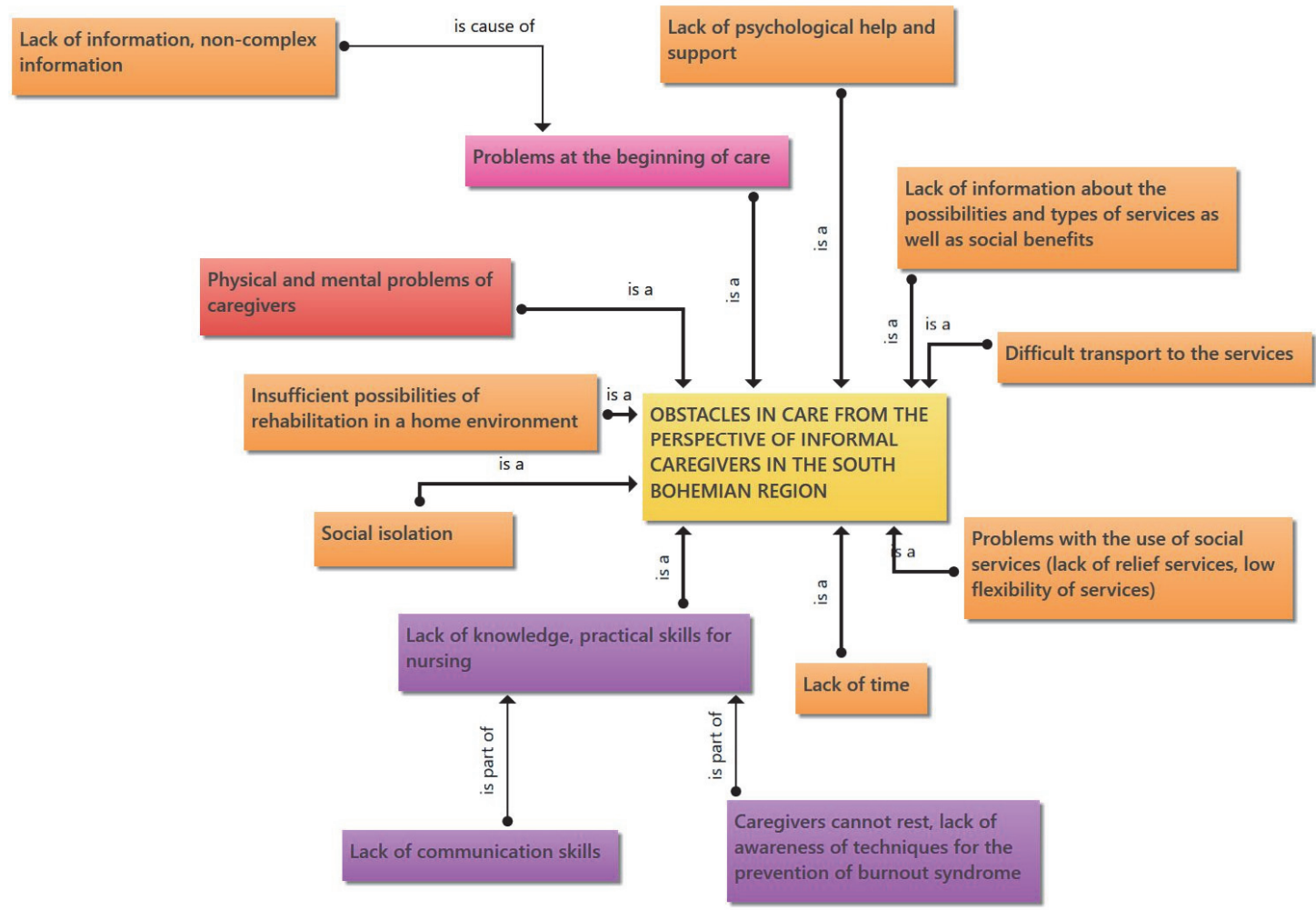

Source: Project No. TL03000518 "Support for informal caregivers in the South Bohemian Region through audio-visual means, including virtual reality", which is supported by the Technology Agency of the Czech Republic within the ÉTA programme.

Fig. 3. Obstacles in care

In-depth interviews revealed the lack of time, insufficient possibility of rehabilitation in a home environment, lack of information on social services, and social security benefits as the most common obstacles in caring for a loved one. The research also found that informal caregivers also lack skills for nursing, such as managing hygiene, positioning, or managing a loved one. Informal caregivers also reported missing communication skills, such as communication with people with dementia or conversations about dying and death. The research revealed the need to strengthen the competencies of informal caregivers so that they can provide their loved ones with adequate care in the home environment and at the same time maintain good physical and mental condition. In such situations, informal caregivers are grateful for all the help from service providers they can get. Research has shown that receiving help is not always the case. "There is a lack of willingness to help" (P5). "And when I wanted the doctor to prescribe me an ambulance be- cause I needed to take her [mother] for a cardiology exam, they told me I wasn't entitled to it. So, I cried, and she told me [the doctor] I needed to take a bus for seniors. I asked her if they had a bed there. She told me she was certain they did when it's for the elderly, so I called there. The lady told me that [the mother] had to walk to it and that she would be sitting there. I said she couldn't do it. She advised me to call my mother's health insurance company and speak with the doctor and describe the situation, and that he would advise me on what to do. So, I called him. He told me to hang up so he could find out everything and call me. The next day he called to say that I could go to our family doctor to ask for an ambulance or to the cardiology department" (P5).

\section{Needs of caregivers}

We focused on informal caregivers' needs. These needs depend on caregivers' age, care length and disability type. It also depends on who helps the informal caregiver and who else the 
informal caregiver has to care for (children, spouse, etc.) and their available financial resources. The interviewed informal caregivers agree in some aspects, such as the decision (not) to put the person they are caring for in an institution, the lack of comprehensive information regarding social support and services, and the disadvantages of care - such as lack of time and exhaustion.

From the results of the in-depth interviews, it is clear that informal caregivers lack time for themselves, information (entitlement to benefits and services), and face back pain associated with the provision of long-term care at home. On the other hand, the responses of informal caregivers included a number of both positive experiences (family cohesion) and negative experiences (communication problems in the extended family). The experiences and concerns of informal caregivers are individual - e.g., marriage breakdown, social isolation, lack of awareness of how to communicate with a person with dementia. These experiences are based on the characteristics of individual "cases". In this context, it is impossible to assess whether the current services for participants are good, bad, satisfactory, unsatisfactory, or insufficient. In this case, however, it is necessary to consider that every caregiver may perceive his or her problem as the most burdensome, stressful, and exhausting. For example, P10 has a problem with the low flexibility of personal assistance: "Personal assistance and other services are not flexible."

\section{Psychological support and help}

Caring for a loved one brings a physical, mental, and emotional burden. In this context, the participants mentioned: "We have less time for ourselves, we are more stressed, we have to deal with more unexpected situations" (P17). "We haven't had any time off since we have had her at home" (P19). "Crazy fatigue. The day will come when I completely collapse" (P16). According to the interviewed informal caregivers, psychological support and help are necessary for managing long-term workload. Among the participants contacted were caregivers, who commented: "I have no one" (P5). "I have no support" (P44). Informal caregivers also stated that they lacked the opportunity for an interview or expert consultation: "Talk to a psychologist" (P35). "What I really miss in today's world are psychologists who focus directly on caring for the long-term ill people" (P35). The above answers suggest the need for psychosocial support and assistance in the various phases of care (Fig. 4), which can help informal caregivers cope with stress and be one of the options for preventing burnout.

\section{Lack of health and social services}

As perceived by the addressed informal caregivers, the lack of health and social services can be divided into two main groups. There are services for informal caregivers and, then, there are services for the persons cared for. Fig. 4 shows the missing services - health and social, and related transport services.

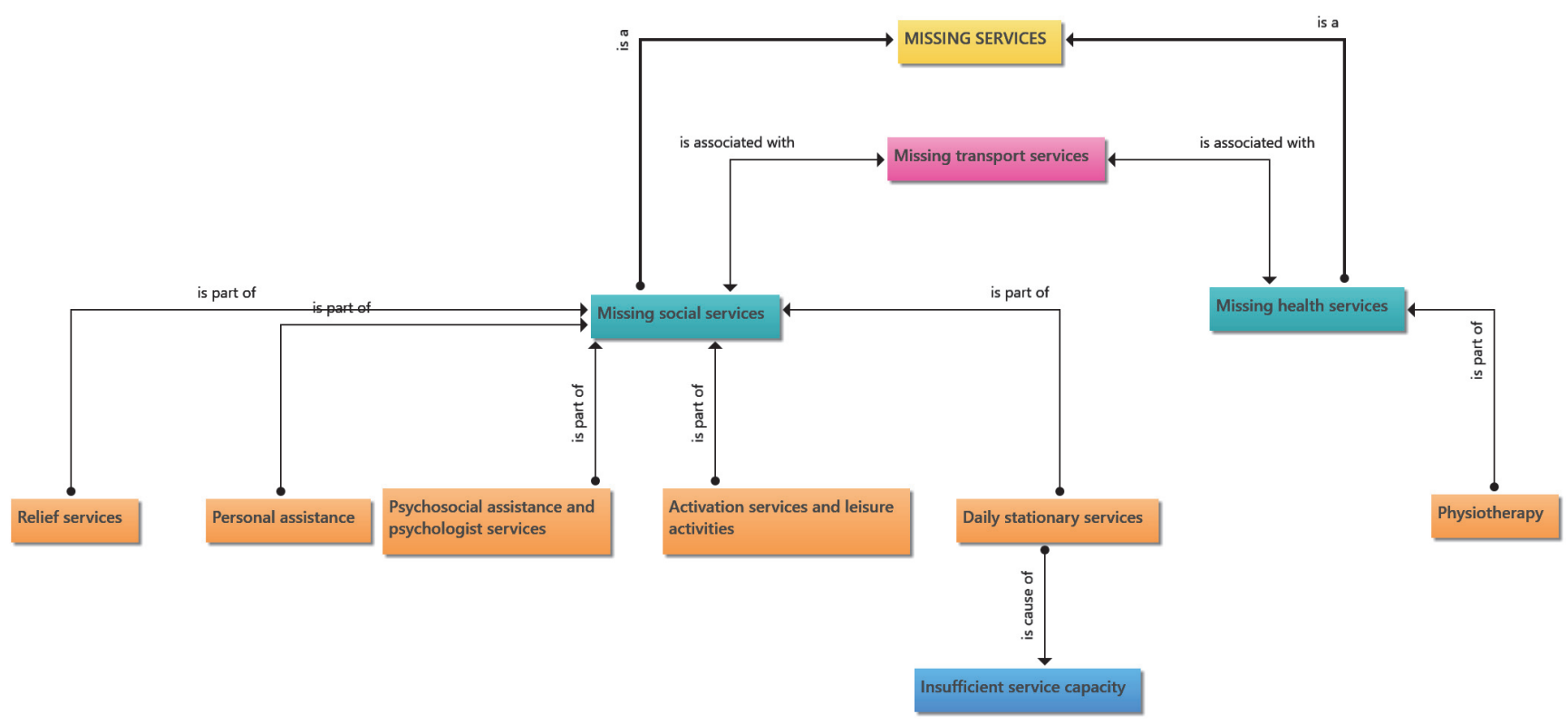

Source: Project No. TL03000518 "Support for informal caregivers in the South Bohemian Region through audio-visual means, including virtual reality", which is supported by the Technology Agency of the Czech Republic within the ÉTA programme.

Fig. 4. Lack of health, social and transport services

We consider it interesting that the participants did not mention the lack of time to use the services for themselves. However, this appeared significantly in other parts of the interview, when lack of time played a crucial role in the disadvantages (negatives) of care. "Well, it's at the expense of all free time" (P2). "I don't have time for myself" (P13). "There is no time to take care of myself, and I don't have time for anything; I live in a rush" (P18). "Our free time and sleep went out of the window" (P33). "It's all up to me. Care has affected my whole life" (P40). "We have lost friends" (P10, P28).
When asked what informal care providers lack or what they lack in the field of services, their answers were dominated by insufficient rehabilitation (physiotherapy) for loved ones. The provision of physiotherapy was also lacking in the home environment. In-depth interviews also revealed a lack of information on the possibilities of using social services and social support. Thus there was a lack of or insufficient information about the types of services and the benefits or allowances to which they are entitled as informal caregivers. "No one offered me any contribution opportunities that I could use" (P21). 
Among the most frequent missing services, the participants mentioned a relief service (field and weekend) and a personal assistance service (e.g., in the form of a personal assistant, including an all-day presence and the possibility of using it on weekends). The addressed informal caregivers are very satisfied with the relief services and consider them to be very beneficial. They would like to use them several times a year, which is unfortunately not possible due to the low capacity of these services. Participants also mentioned the insufficient capacity of daily stationary services. Those in the South Bohemian Region lack activation, leisure activities and a transport service for their loved ones. The problem often arises when transport is necessary, e.g., when one cannot use public transport for various reasons (at the time of a viral disease epidemic, lack of self-sufficiency, immobility, lack of transport connection, etc.). Participants who would like to use personal assistance services cannot use them due to financial demands. "I think the possibility of personal assistance would help me a lot, but it is a financially unimaginable matter" (P35). Based on the participants' views, we can say that the absence or lack of services is related to social services more than health services.

\section{Discussion}

Informal care (short-term and long-term) and the issue of caregivers are among the essential topics in the Czech Republic in relation to health and social policy and are included in the National Strategy for the Development of Social Services 2016-2025 (MoLSA CR, 2015). Geisler et al. (2015a, b; 2019) comprehensively dealt with the issue of informal caregivers. The authors specifically dealt with mapping informal care, the proposal to support informal care, the needs of informal caregivers and support policy for informal caregivers. The issue of informal caregivers was also addressed in the research of Klímová Chaloupková (2013), Dudová and Vyhlídalová (2018), and Kř́ižová et al. (2016).

This research focused on identifying selected areas that informal caregivers encounter regarding the care of a loved one in the home environment in the South Bohemian Region. The partial goal was to find out what problems informal caregivers faced regarding social or health services. Informal caregivers lack competencies in nursing care (hygiene, positioning, managing a loved one) and communication. Geissler et al. (2019) state that 1.5 to 2 million adults in the Czech Republic are involved in caring for loved ones at least in a minimal way. Informal (lay) care in the Czech Republic includes children with disabilities, adults and seniors (from 65 years) - i.e., different target groups, which must receive a different approach when they are provided with comprehensive care. This also applies to varying approaches to care and communication. The data obtained from the research are in close agreement with Brémault-Phillips et al. (2016). Barriers to care provided by informal caregivers include the increasing demands on time, resources and access to them, changing roles and responsibilities in the family, emotional responses to provided care, social dynamics and the caregiver's health, and the unawareness of coping techniques (Brémault-Phillips et al., 2016).

The research showed that informal caregivers do not have the necessary knowledge and skills related to home care. Informal caregivers, therefore, need to strengthen the required competencies for caring so that they can provide quality care to their loved ones while maintaining their physical and mental health. Caring for a loved one in the home environment is physically and mentally demanding, and it is necessary to prevent burnout syndrome due to the long-term stress. Informal caregivers, like formal caregivers, are at risk of developing burnout. According to Kozáková et al. (2017), burnout syndrome was found in family caregivers to a greater extent than in professional caregivers. Similar to Přidalová (2006), our research has shown the emotional commitment of informal caregivers, which often puts the burden of caring on them. It is characterised by physical and mental fatigue, and social and financial problems associated with caring for people with disabilities.

Given the obtained results, the authors propose that informal caregivers devote themselves to comprehensive education whether they care for a child or an adult with a disability (e.g., with a physical disability, combined disability, autism spectrum disorder) or seniors (from 65 years). These courses can be offered by non-governmental, non-profit organisations, universities in lifelong learning, universities of the third age and other educational institutions, and peer consultants from the ranks of informal caregivers. Increasing the support of caregivers through health and social services and improving the information and education of informal caregivers are among the goals of the National Strategy for the Development of Social Services for the period 2016-2025 (MoLSA CR, 2015). Vacková et al. (2020) recommend setting up effective interventions specifically in caring for a person with brain damage in the home environment.

From our perspective, it seems essential to prepare seminars/courses for informal caregivers regarding communication in order for them to understand the specifics and communicate effectively with the people they care for. Communication management is necessary for quality informal care. Lack of knowledge and skills in communication can lead to misunderstandings, problems, and dissatisfaction, usually on both sides (Malíková, 2020). The barriers that informal caregivers mentioned included the lack of information about the possibilities of using social services and contributions and social benefits. Caregivers also need information, advice, and counselling, which they perceived as psychological help and often lacked in caring. Similarly, Jansen et al. (2019) and Van Houtven et al. (2019) commented on training and sharing practical experience. Nursing professionals have an essential role in educating and supporting caregivers. They can take the lead in implementing interventions regarding the skills and unmet needs of caregivers (Shepherd-Banigan et al., 2020). Informal caregivers need comprehensive information on entitlement and financial support options for caregivers and the people they care for. The performance of social work in municipalities and municipalities with extended authority seems necessary, where a social worker is engaged in counselling, dispensary and screening activities, and can also be a coordinator of longterm care.

In terms of missing services, participants mentioned mainly social services - relief services (field and weekend), personal assistance (all-day, weekend) and its unavailability, insufficient capacity of daily stationary services, lack of activation and leisure activities, and missing transport services. When providing health and social services, it is necessary to consider regional specifics, which take into account not only the needs of clients but also the possibilities of service providers. Our results correspond with practice, which shows difficulties with the availability of some social services in some regions. The availability of field services is insufficient and, above all, significantly uneven - the worst situation is on the border between regions and remote areas. There is also a lack of interconnectedness, integrity and coordination of services 
or information for clients and their families about the range and use of services (Čeledová et al., 2016). Regarding the price for personal assistance, the maximum financial amount is set to CZK 130 per hour by the implementing decree of the Ministry of Labour and Social Affairs of the Czech Republic No. 505/2006 Coll. to the Act on Social Services No. 108/2006 Coll., on social services. The adopted legislation has proved to be incomplete and not reflecting practice. The legislation on social services is currently being updated.

Research has shown the need for an individual assessment of the needs and situation of informal caregivers. This finding corresponds to the situation in other EU countries, such as Belgium, Luxembourg, and Italy, where a systematic assessment of the condition of informal caregivers is already underway (Cès and Coster, 2019). The review of caregivers' needs, and objectives varies from country to country, and is often linked to legal support measures for informal caregivers - cash benefits, time off (Cès and Coster, 2019). The Czech Republic still lacks direct support from informal caregivers. From our perspective, supporting the quality of life and healthy lifestyle of informal caregivers requires a comprehensive view and cooperation across the entire spectrum of scientific and social disciplines, including a multidisciplinary approach. The current development of new technologies in audio-visual technology and virtual reality offers new education methods, knowledge dissemination, skills, and experience, even for informal caregivers. Virtual reality is one of the possibilities and innovative approaches for informal caregivers in psychosocial support. It can be used for relaxation techniques and training in coping with difficult life situations related to care and thus prevent burnout syndrome.

\section{Applying the obtained results to practice}

The obtained results will be used in other phases of the project, which will be related to the support of informal caregivers in the South Bohemian Region through individual or group counselling and participation in a self-help group. Comprehensive counselling will be provided by a multidisciplinary team consisting of a psychologist, social worker, sociologist, general nurse, physiotherapist, and expert in creating a virtual reality application. The individual counselling services will be divided into four areas: (1) psychosocial counselling, (2) counselling regarding a healthy lifestyle, (3) professional social counselling and (4) professional counselling regarding comprehensive nursing care for immobile/partially immobile clients.

Psychosocial counselling will focus on crises and their management, the prevention and early detection of burnout, the practice of relaxation techniques and mental health care. In this exercise, virtual reality will also be used, which will focus on relieving tension and stress, activating internal resources, obtaining resources for drawing energy, and meditation.
Counselling regarding a healthy lifestyle will focus on caring for the musculoskeletal system, nutrition, and the prevention of diseases of civilisation. Professional social counselling will cover state social support benefits and material need, the possibility of using social services, and social and legal counselling, and compensatory aids. As part of direct support, in individual or group form, informal caregivers will be provided with professional counselling in comprehensive nursing care for immobile or partially immobile clients. This counselling will aim to practice nursing care and rehabilitation for immobile people, including the use of modern compensatory aids. The self-help group will be designed for informal caregivers. It will aim to provide mutual support and sharing, exchange of experience, and information on caring for a loved one at home.

\section{Conclusions}

This article presents the results of qualitative research pointing to the lack of health and social services that informal caregivers would welcome in the South Bohemian Region. It also points out the obstacles related to the care provided to loved ones and the needs that are not met in this target group. The qualitative research carried out in the South Bohemian Region revealed the need and necessity of strengthening the competencies of informal caregivers regarding the provision of direct care. The results also showed the need to provide psychosocial support and comprehensive counselling to informal caregivers. Furthermore, educational courses or workshops increase the awareness and competencies of informal caregivers. According to the interviewed informal caregivers, such courses are needed, especially at the beginning of caring for a loved one. In this context, it seems crucial to map the individual needs of individual informal caregivers in the South Bohemian Region and, on that basis, to provide them with adequate counselling and other services based on their specific requirements.

\section{Ethical aspects and research limitations}

The authors declare that there is no conflict of interests in the content or publication of the article. Participants were informed in advance about the purpose of the research and agreed that their results could be included in the research setting.

\section{Acknowledgements}

This publication was created with the state support of the Technology Agency of the Czech Republic within the ÉTA programme, and project No. TL03000518 "Support of informal caregivers in the South Bohemian Region through audio-visual means, including virtual reality". The authors of the article would like to thank all the participants in the research. 


\section{Překážky v péči a chybějící služby z pohledu neformálních pečovatelů v Jihočeském kraji}

\section{Souhrn}

Úvod: Neformální péče jako součást systému dlouhodobé péče a problematika pečujících osob je vzhledem k potřebnosti a aktuálnosti zařazena v ČR do Národní strategie rozvoje sociálních služeb 2016-2025.

Cíl: Cílem kvalitativního výzkumu bylo identifikovat vybrané oblasti, se kterými se neformální pečovatelé setkávají v souvislosti s péčí o blízkou osobu v domácím prostředí v Jihočeském kraji. Dílčím cílem bylo zjistit, s jakými problémy se neformální pečovatelé setkávají v souvislosti s využíváním sociálních či zdravotních služeb.

Metodika: Analyzováno bylo celkem 44 hloubkových rozhovorů s 45 neformálními pečovateli. Participanti byli vybráni technikou „snowball sampling“ a výběrem přes instituce. Rozhovory byly zpracovány v programu ATLAS.ti, verze.

Výsledky: Mezi překážky v rámci neformální péče patří nedostatek času, nedostatečná možnost fyzioterapie v domácím prostředí, chybějící informace o možnostech využití i druhu služeb a nároku na dávky. Neformální pečovatelé postrádají odlehčovací služby, osobní asistenci, aktivizační služby, volnočasové aktivity a transportní službu.

Závěr: Vzhledem k náročnosti neformální péče musí být součástí komplexního přistupu péče o pečující osoby. Doporučujeme posílit kompetence neformálních pečovatelů prostřednictvím komplexního poradenství a dalších služeb, a to s ohledem na individuální potřeby neformálních pečovatelů v Jihočeském kraji.

Klíčová slova: chybějící služby; Jihočeský kraj; neformální péče; péče o osobu blízkou, potřeby pečovatelů; překážky v péči

\section{References}

1. Act on Social Services No. $108 / 2006$ Coll., on social services (zákon č. 108/2006 Sb., o sociálních službách). In: Sbírka zákonů České republiky, částka 37/2006, pp. 1257-1289.

2. Akgun-Citak E, Attepe-Ozden S, Vaskelyte A, van BruchemVisser RL, Pompili S, Kav S, et al. (2020). Challenges and needs of informal caregivers in elderly care: Qualitative research in four European countries, the TRACE project. Arch Gerontol Geriatr 87: 103971. DOI: 10.1016/j.archger.2019.103971.

3. Barbabella F, Poli A, Santini S, Lamura G (2018). The role of informal caregivers in long-term care for older people. In: Boll T, Ferring D, Valsiner J (Eds). Cultures of care in aging. Charlotte: Information Age Publishing, pp. 193-212.

4. Brémault-Phillips S, Parmar J, Johnson M, Huhn A, Mann A, Tian V, et al. (2016). The voices of family caregivers of seniors with chronic conditions: a window into their experience using a qualitative design. SpringerPlus 5: 620. DOI: 10.1186/s40064016-2244-z.

5. Čeledová L, Kalvach Z, Čevela R (2016). Úvod do gerontologie. Praha: Univerzita Karlova, Karolinum, 148 p.

6. Cès $S$, Coster $S$ (2019). Mapping long-term care quality assurance practices in the EU - Summary Report. European Social Policy Network (ESPN). Brussels: European Commission.

7. Decree of the Ministry of Labour and Social Affairs of the Czech Republic No. 505/2006 Coll (vyhláška č. 505/2006 Sb., kterou se provádějí některá ustanovení zákona o sociálních službách). In: Sbírka zákonů České republiky, částka 164/2006.

8. Dixe M dos ACR, da Conceição Teixeira LF, Areosa TJTCC, Frontini RC, de Jesus Almeida Peralta T, Querido AIF (2019). Needs and skills of informal caregivers to care for a dependent person: a cross-sectional study. BMC Geriatr 19: 255. DOI: 10.1186/s12877-019-1274-0.

9. Dudová R, Vohlídalová M (2018). Muži a ženy pečující o seniory v rodině. Sociologický časopis / Czech Sociological Review 54(2): 219-252. DOI: 10.13060/00380288.2018.54.2.400.

10. Geissler H, Fischerová A, Holeňová E, Solnářová D, Staňková N (2019). Jak podporovat pečující na regionální a lokální úrovni? Př́klady dobré praxe. Praha: Fond dalšího vzdělávání, 90 p. [online] [cit. 2020-12-08]. Available from: https://pecovatazit.cz/assets/uploads/sites/1071/2019/06/ KA1.1_Jak-podporovat-pe\%C4\%8Duj\%C3\%ADc\%C3\%ADna-region\%C3\%A1ln\%C3\%AD-a-lok\%C3\%A1ln\%C3\%AD\%C3\%BArovni_P\%C5\%99\%C3\%ADklady-dobr\%C3\%A9-praxe. pdf

11. Geissler $\mathrm{H}$, Holeňová $\mathrm{E}$, Horová $\mathrm{T}$, Jirát $\mathrm{D}$, Solnářová $\mathrm{D}$, Schlanger J, et al. (2015a). Výstupní analytická zpráva o současné situaci a potřebách pečujících osob a bariérách pro poskytování neformální péče v ČR. Praha: Fond dalšího vzdělávání, 118 p. [online] [cit. 2020-11-10]. Available from: https://nepe.cz/nepe1.php

12. Geissler $H$, Holeňová $E$, Horová $T$, Jirát $D$, Solnářová $D$, Tomášková V (2015b). Návrh politiky na podporu neformálních pečovatelů. Praha: Fond dalšího vzdělávání, 93 p. [online] [cit. 2020-12-15]. Available from: https://drive.google.com/file/d/1 XoOzalJ9XvxNBrCS_AQny0Nnr3HdzKG/view

13. Gerbery D, Bednárik R (2018). ESPN Thematic Report on Challenges in long-term care, Slovakia. Brussels: European Commission. [online] [cit. 2020-11-14]. Available from: https:// ec.europa.eu/social/BlobServlet?docId=19867\&langId=en

14. Jansen, L, Eecloo, L, Vanwing, A, Schoenmakers, B (2019). You never walk alone: An exploratory study of the needs and burden of an informal care group. Health Soc Care Community 27(2): 375-382. DOI: 10.1111/hsc.12655.

15. Klímová Chaloupková J (2013). Neformální péče v rodině: sociodemografické charakteristiky pečujících osob. Data a výzkum-SDA Info 7(2), 107-123.

16. Kozáková R, Vévodová Š, Vévoda, J, Merz L, Grygová B, Kozák J (2017). Syndrom vyhoření u rodinných a profesionálních pečujících. Profese Online 10(1): 1-7. DOI: 10.5507/ pol.2017.001.

17. Kř́žová E, Janečková H, Běláček J (2016). Family Caregivers' Perspectives on Integrated Community Care in the Czech Republic. Cent Eur J Public Health 24(4): 289-296. DOI: 10.21101/cejph.a4463.

18. Lindeza P, Rodrigues M, Costa J, Guerreiro M, Rosa MM (2020). Impact of dementia on informal care: a systematic review of family caregivers' perceptions. BMJ Support Palliat Care, bmjspcare-2020-002242. DOI: 10.1136/ bmjspcare-2020-002242.

19. Malíková E (2020). Péče o seniory v pobytových zařízeních sociálních služeb. 2nd updated and supplemented ed. Praha: Grada Publishing, 304 p.

20. MoLSA CR (2015). National Strategy for the Development of Social Services 2016-2025 (MPSV ČR - Národní strategie rozvoje sociálních služeb 2016-2025). [online] [cit. 2021-02-03]. Available from: https://www.mpsv.cz/ documents/20142/577769/NSRSS.pdf/af89ab84-31ac-e08a7233-c6662272bca0

21. Přidalová M (2006). Péče o staré rodiče - nový úděl mladších seniorů? Caring for old parents - new life stage of younger seniors? Sociální práce: odborná revue pro sociální práci (2): 68-81.

22. Schön P, Heap J (2018). ESPN Thematic Report on Challenges in long-term care, Sweden. Brussels: European Commission. 
23. Shepherd-Banigan M, Kaufman BG, Decosimo K, Dadolf J, Boucher NA, Mahanna EP, et al. (2020). Adaptation and Implementation of a Family Caregiver Skills Training Program: From Single Site RCT to Multisite Pragmatic Intervention. J Nurs Scholarsh 52(1): 23-33. DOI: 10.1111/jnu.12511.

24. Triantafillou J, Naiditch M, Repkova K, Stiehr K, Carretero S, et al. (2010). Informal care in the long-term care system. European Overview Paper. Athens/Vienna, 67 p. [online] [cit. 2021-01-05]. Available from: https://www.euro.centre.org/ downloads/detail/768

25. Vacková J, et al. (2020). Sociální práce v systému koordinované rehabilitace u klientů po získaném poškození mozku (zejména CMP) se zvláštním zřetelem na intervenci z hlediska sociální práce, fyzioterapie, ergoterapie a dalších vybraných profesí. Praha: Grada Publishing, 208 p. DOI: 10.32725/ zsf.2020_124343.
26. Van Houtven $\mathrm{CH}$, Smith VA, Lindquist JH, Chapman JG, Hendrix C, Hastings SN, et al. (2019). Family Caregiver Skills Training to Improve Experiences of Care: a Randomized Clinical Trial. J Gen Intern Med 34(10): 2114-2122. DOI: 10.1007/ s11606-019-05209-x.

27. Verbakel E, Tamlagsrønning S, Winstone L, Fjær EL, Eikemo TA (2017). Informal care in Europe: findings from the European Social Survey (2014) special module on the social determinants of health. Eur J Public Health 27(Suppl. 1): 90-95. DOI: 10.1093/eurpub/ckw229.

28. Zigante V (2018). Informal care in Europe Exploring Formalisation, Availability and Quality. Luxemburg: Publications Office of the European Union. [online] [cit. 2020-11-15]. Available from: http://cite.gov.pt/pt/destaques/ complementosDestqs2/Informal_care.pdf 